\title{
Review
}

Journal of Innate

Immunity
J Innate Immun 2012;4:225-240

DOI: $\underline{10.1159 / 000335900}$
Received: September 6, 2011

Accepted after revision: December 14, 2011

Published online: March 6, 2012

\section{Pattern Recognition Receptors in Immune Disorders Affecting the Skin}

\author{
Heleen D. de Koning ${ }^{a-e}$ Anna Simon ${ }^{b, d, e}$ Patrick L.J.M. Zeeuwen ${ }^{a, c, d}$ \\ Joost Schalkwijk ${ }^{\mathrm{a}, \mathrm{c}-\mathrm{e}}$
}

Departments of a Dermatology and ${ }^{\mathrm{b}}$ Medicine, Radboud University Nijmegen Medical Centre, ${ }^{\mathrm{C} N i j m e g e n ~ C e n t r e ~}$

for Molecular Life Sciences (NCMLS), d Nijmegen Institute for Infection, Inflammation and Immunity (N4i), and

eN4i Centre for Immunodeficiency and Autoinflammation, Nijmegen, The Netherlands

\section{Key Words}

Autoimmunity $\cdot$ Epithelium $\cdot$ Host defense $\cdot$ Immune response $\cdot$ Pathogen-associated molecular patterns . Pattern recognition receptors $\cdot$ Toll-like receptor $\cdot$ Skin

\section{Abstract}

Pattern recognition receptors (PRRs) evolved to protect organisms against pathogens, but excessive signaling can induce immune responses that are harmful to the host. Putative PRR dysfunction is associated with numerous immune disorders that affect the skin, such as systemic lupus erythematosus, cryopyrin-associated periodic syndrome, and primary inflammatory skin diseases including psoriasis and atopic dermatitis. As yet, the evidence is often confined to genetic association studies without additional proof of a causal relationship. However, insight into the role of PRRs in the pathophysiology of some disorders has already resulted in new therapeutic approaches based on immunomodulation of PRRs.

\section{Introduction}

Pattern recognition receptors (PRRs) are a vital part of innate host defense. In several diseases, however, PRR signaling can be harmful to the host. Tissue damage can be inflicted by excessive pathogen-induced PRR signaling. Yet during the last decade several diseases were identified in which profuse PRR signaling was caused by endogenous factors. The cryopyin-associated periodic syndrome (CAPS) is an example of genetically predisposed NLRP3 [nucleotide oligomerization domain (NOD), leucin-rich repeat- and pyrin domain-containing 3 protein] overactivation, resulting in mild to debilitating systemic inflammation $[1,2]$. Multiple complex disorders have been linked to NLRP3 dysfunction, including gout, type 2 diabetes mellitus and atherosclerosis $[1,3,4]$. Although NLRP3 is the best-characterized inflammasome-related PRR, and it was shown to respond to an impressive array of endogenous and exogenous stimuli ranging from ATP to reactive oxygen species, the exact ligand sensing mechanism of NLRP3 remains unknown [5]. NLRP3 is part of an inflammasome. Inflammasomes are multiprotein complexes that upon ligand binding by certain PRRs activate caspase-1, which in turn activates the potent pro-

\section{KARGER \\ Fax +41613061234 \\ E-Mail karger@karger.ch}

www.karger.com
2012 S. Karger AG, Basel

$1662-811 X / 12 / 0043-0225 \$ 38.00 / 0$

Accessible online at: www.karger.com/jin
Dr. Heleen Dian de Koning

Department of Dermatology, Radboud University Nijmegen Medical Centre PO Box 9101

NL-6500 HB Nijmegen (The Netherlands)

Tel. +31 24361 4093, E-Mail h.dekoning@ derma.umcn.nl 


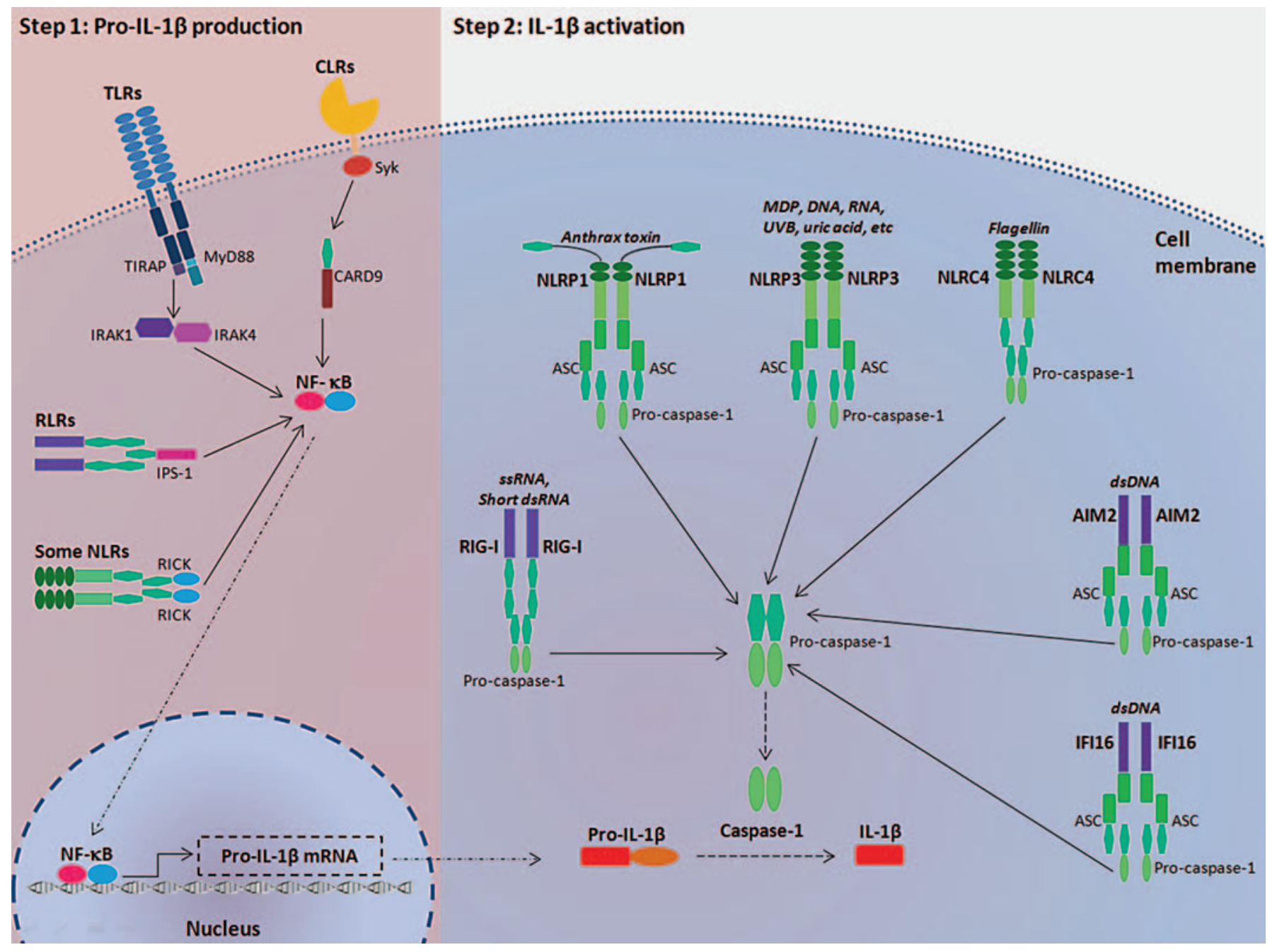

Fig. 1. The inflammasomes. Inflammasomes are protein complexes that activate caspase-1, which in turn activates the proinflammatory cytokine IL-1 $\beta$. IL- $1 \beta$ production requires two signals. First, activation of multiple PRRs may lead to NF- $\kappa \mathrm{B}$ activation, resulting in the production of pro-IL-1 $\beta$, the precursor of IL-1 $\beta$. Second, activation of an inflammasome results in activation of caspase-1, which in turn cleaves pro-IL-1 $\beta$ into the active cytokine. The PRRs that associate with inflammasomes are NLRP1, NLRP3, NLRC4, AIM2, IFI16 and RIG-I, each recognizing particular PAMPs and DAMPs. The adaptor protein ASC is required in all inflammasome complexes to bridge the interaction between upstream PRRs and inflammatory caspases through its amino-terminal pyrin domain (PYD) and carboxy-terminal CARD, respectively. The major ligands of the PRRs are depicted in bold. NLRP1 = Nucleotide-binding oligomerization domain (NOD)-like receptor (NLR) family PYD-containing protein 1. Adaptor and signaling proteins: IRAK = IL-1R-associated kinase; SYK = spleen tyrosine kinase; ASC = apoptosis-associated specklike protein containing a CARD; ssRNA = single-stranded RNA; $\mathrm{MDP}=$ muramyl dipeptide; $\mathrm{UVB}=$ ultraviolet $\mathrm{B}$ radiation. inflammatory cytokines IL-1 $\beta$, IL-18 and IL-33 (fig. 1). Since IL-1 $\beta$ is an extremely potent inflammatory cytokine, its activation is strictly regulated and requires more than inflammasome activation. The two-step model of IL- $1 \beta$ activation holds that prior to inflammasome activation the precursor of IL-1 $\beta$ (pro-IL-1 $\beta$ ) needs to be transcribed, for which priming with TLR ligands or cytokine tumor necrosis factor- $\alpha$ (TNF- $\alpha)$ is required (fig. 1) $[5,6]$. This is one of the many cases in which PRR cooperation is imperative. The PRRs that associate with inflammasomes are the NLRs NLRP1, NLRP3, NLRC4 [NOD-, leucin-rich repeat- and caspase-associated recruitment domain (CARD)-containing 4] [7], the DNA sensors AIM2 (absent in melanoma 2) [8-10] and IFI16 (interferon, gamma-inducible protein 16) [11], and RIG-I (retinoic-acid-inducible gene I) [12]. 
The levels of evidence for associations between diseases and PRRs differ greatly. In some, there is a clear causal relationship between a mutation in a PRR gene and excessive inflammation, whereas in other diseases, only differences in expression levels of certain PRRs or associations with single nucleotide polymorphisms (SNPs) in genome-wide association studies were reported. This review summarizes the detrimental roles PRRs can play in primary inflammatory skin diseases and systemic diseases with skin manifestations.

\section{PRRs as Villains in Primary Skin Disorders}

Despite the fact that these disorders principally affect the skin, several of them can also give systemic symptoms, and can display abnormalities in circulating immune cells or inflammatory mediators. The inflammatory skin disorders that are associated with PRRs are listed in table 1 .

\section{Primary Skin Disorders in Which a Role of PRRs Is Suspected}

Psoriasis

Psoriasis is a chronic inflammatory skin disease characterized by erythematosquamous plaques. It is associated with skin barrier abnormalities and $\mathrm{T}$ helper cell 1 (Th1) and Th17 immune responses [13, 14]. More recently, the innate immune system was found to play a role too. The expression of multiple antimicrobial proteins (AMPs), including human $\beta$-defensin-2 (hBD-2), is strongly increased in psoriatic plaques [13], which could well be a downstream effect of PRR signaling. Several groups investigated PRR expression in psoriatic lesions. Lesional TLR2 $\mathrm{mRNA}$ and protein expression levels are similar to those in normal skin $[15,16]$, although two older studies suggested differently [17, 18]. Transforming growth factor alpha, which is induced in psoriasis, was shown to increase TLR5 and TLR9 expression and function in keratinocytes. TLR2, TLR5 and TLR9 ligands induce the expression of human $\beta$-defensins in primary keratinocytes $[15,19]$. Also, TLR2, TLR3 and TLR4 ligands were shown to induce the psoriasis-associated cytokine TNF- $\alpha$ in human keratinocytes [18]. It is, however, controversial whether TLR4 is expressed in primary human keratinocytes, because several authors did not find TLR4 expression or effects of lipopolysaccharide (LPS) stimulation in these cells $[15,20]$.

Interestingly, topical application of imiquimod, a ligand for both TLR7 and TLR8, has been described as aggravating psoriatic lesions, but also inducing de novo psoriasis [21-24]. TLR7 and TLR8 signaling leads to a type I interferon (IFN) response. IFN- $\alpha$-producing plasmacytoid dendritic cells (pDCs) are thought to be important in the induction of psoriasis [25]. Moreover, psoriasis was reported to be induced or exacerbated by treatment with IFN- $\alpha$ or IFN- $\beta$ for various indications (hepatitis C [26], chronic myeloid leukemia [27] or multiple myeloma [28]). In a mouse model, daily application of imiquimod induced psoriasis-like lesions with increased epidermal expression of IL-23, IL-17A and IL-17F, and an increase in splenic Th17 cells. However, this phenotype was prevented in mice deficient in the IL-23 or IL-17 receptor. This study provided a link between TLR7 or TLR8 signaling and the IL-23/IL-17 axis, which is important in the pathogenesis of psoriasis [29]. The role of other type I IFN-inducing PRRs is unclear, since in one study RIG-I and MDA5 (melanoma differentiation-associated gene 5) were slightly upregulated [30], while others did not find any difference in RLR (RIG-like helicase receptor family) expression levels [15].

A meta-analysis demonstrated a lack of association between NOD2 polymorphisms and psoriasis and psoriatic arthritis, suggesting that this NLR is not a susceptibility gene for psoriasis [31].

Compared to normal skin, the CLR dectin-1 is increased in the epidermis in psoriatic plaques at both the mRNA and protein level. MRC1 (macrophage mannose receptor 1) mRNA expression was also upregulated [15]. In monocytes and macrophages, dectin-1 signaling induces IL-23, which in turn promotes differentiation of Th17 cells [32]. As a sensor of fungal $\beta$-glucan, dectin-1 signaling stimulates immune cells to produce antifungal AMPs, which are highly expressed in psoriasis lesions. Stimulation of primary human keratinocytes with $\beta$ glucan or heat-killed Candida, however, did not induce proinflammatory cytokines or AMPs, either with or without TLR2, TLR5 or MRC1 costimulation [15]. Possibly, dectin-1 expression levels were too low for proper functioning, or costimulation with other ligands is required.

LL37, one of the upregulated AMPs in psoriasis, forms aggregates with extracellular self-DNA that can enter pDCs, activate TLR9 and trigger type I IFN production [33]. Recently, LL37 was reported to neutralize cytosolic DNA in keratinocytes and block activation of the AIM2 inflammasome. The authors found upregulation of AIM2 in psoriatic lesional skin and a 3-fold induction of IL- $1 \beta$ secretion by keratinocytes upon stimulation with doublestranded DNA (dsDNA) [34]. 
Table 1. PRRs implicated in immune disorders affecting the skin

\begin{tabular}{|c|c|c|c|c|}
\hline Disease & Genetic association & $\begin{array}{l}\text { Endogenous expression in } \\
\text { affected human tissues }\end{array}$ & $\begin{array}{l}\text { PRR-mediated effect on immune } \\
\text { response to ligands in human cells }\end{array}$ & $\begin{array}{l}\text { Functional association } \\
\text { in mice }\end{array}$ \\
\hline \multicolumn{5}{|c|}{ Primary skin disorders } \\
\hline \multicolumn{5}{|c|}{$\begin{array}{l}\text { In keratinocytes: } \\
\text { TLR2: induction of hBD- } 2 \text { and TNF- } \alpha \\
\text { TLR3: induction of TNF- } \alpha \\
\text { TLR4: induction of TNF- } \alpha \text { or no effect } \\
\text { TLR5: induction of hBD-2 } \\
\text { TLR9: induction of hBD-2 } \\
\text { Dectin-1: no effect of } \beta \text {-glucan }+/- \\
\text { TLR2 or TLR5 or MRC1 ligands } \\
\text { AIM2: IL-1 } \beta \text { activation } \\
\text { In monocytes: } \\
\text { Dectin- } 1 \text { : induction of IL- } 23\end{array}$} \\
\hline $\mathrm{AD}$ & $\begin{array}{l}\text { TLR2 A-16934T promotor SNP: } \\
\text { disease severity } \\
\text { TLR2 R753Q SNP: disease severity } \\
\text { and increased colonization with } \\
\text { S. aureus } \\
\text { TLR9 C-1237T promotor SNP: } \\
\text { association in subgroup } \\
\text { NOD1 SNPs: association in some }\end{array}$ & $\begin{array}{l}\text { Dectin-1: increased } \\
\text { MRC1: increased } \\
\text { TLR1: increased } \\
\text { TLR2: normal or } \\
\text { decreased }\end{array}$ & $\begin{array}{l}\text { In keratinocytes: } \\
\text { TLR2/TLR6: induction of TSLP }\end{array}$ & \\
\hline $\mathrm{ACD}$ & & & $\begin{array}{l}\text { MyD88 RNAi: inhibited } \\
\text { nickel-induced inflammation } \\
\text { IRAK1 RNAi: reduced } \\
\text { nickel-induced inflammation } \\
\text { TLR4 RNAi: inhibited } \\
\text { nickel-induced inflammation } \\
\text { Caspase-1: mediated IL-1 } \beta \text { activation } \\
\text { upon TNCB and SDS }\end{array}$ & $\begin{array}{l}\text { Tlr2-/-/Tlr4-/-: } \\
\text { impaired TNCB-induced } \\
\text { ACD } \\
\text { Tlr4-/-: no effect on } \\
\text { TNCB-induced ACD } \\
\text { hTLR4, not } m \text { Tlr4: } \\
\text { mediated nickel-induced } \\
\text { ACD } \\
\text { Asc-/-: reduced } \\
\text { TNCB-induced ACD } \\
\text { Nlrp3-/-: reduced } \\
\text { TNCB-induced ACD } \\
\text { Nlrp12-/-: reduced } \\
\text { oxazolone or FITC ACD }\end{array}$ \\
\hline
\end{tabular}

Primary skin disorders in which a role of PRRs is speculative

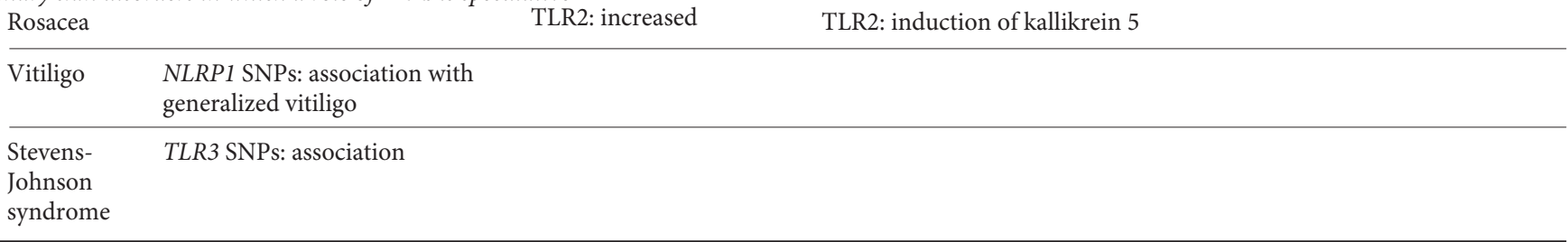

\section{Systemic immune disorders affecting the skin}

Monogenic disorders directly linked to a mutation in a PRR gene

CAPS NLRP3 mutations: autosomal

dominant, disease-causing

NLRP3 mutants: excessive

endogenous and PAMP-induced

IL- $1 \beta$ activation

NLRP12AD NLRP12 mutations: autosomal

dominant (?), disease-causing

NLRP12 mutants: impaired inhibition

of NF- $\mathrm{KB}$ signaling in some;

increased IL- $1 \beta$ and ROS activation in

others

Blau NOD2 mutations:

NOD2 mutants: constitutive

syndrome disease-causing

activation of NF- $\mathrm{KB}$ 
Table 1 (continued)

\begin{tabular}{|c|c|c|c|c|}
\hline Disease & Genetic association & $\begin{array}{l}\text { Endogenous expression in } \\
\text { affected human tissues }\end{array}$ & $\begin{array}{l}\text { PRR-mediated effect on immune } \\
\text { response to ligands in human cells }\end{array}$ & $\begin{array}{l}\text { Functional association } \\
\text { in mice }\end{array}$ \\
\hline \multicolumn{5}{|c|}{ Disorders caused by overstimulation of $P R R$ by endogenous ligands } \\
\hline $\begin{array}{l}\text { Systemic immun } \\
\text { BD }\end{array}$ & $\begin{array}{l}\text { disorders in which a role of PRRs is } \\
\text { TLR4 SNP: more prevalent in } \\
\text { HLA-B51+ patients } \\
\text { TIRAP SNP: associated in one } \\
\text { population }\end{array}$ & suspected & & \\
\hline GVHD & $\begin{array}{l}\text { NOD2 SNPs: increased } \\
\text { susceptibility }\end{array}$ & & & $\begin{array}{l}\text { Recipient Tlr9-/-: } \\
\text { reduced GVHD } \\
\text { Donor Tlr9-/-: no effect } \\
\text { Tlr9 blocking by iODN: } \\
\text { reduced GVHD } \\
\text { Recipient Myd88: no effect } \\
\text { Recipient TRIF: no effect } \\
\text { Recipient TLR2-/-: no effect } \\
\text { Recipient TLR4-/-: no effect } \\
\text { or more severe GVHD } \\
\text { Donor TLR4-/-: no effect or } \\
\text { reduced GVHD } \\
\text { Recipient NOD2-/-: } \\
\text { more severe GVHD } \\
\text { Donor NOD2-/-: no effect }\end{array}$ \\
\hline $\begin{array}{l}\text { Systemic immun } \\
\text { Sarcoidosis }\end{array}$ & $\begin{array}{l}\text { disorders in which a role of } P R R s \text { is } \\
\text { NOD2 SNPs: association with } \\
\text { severe pulmonary disease, not in } \\
\text { general }\end{array}$ & peculative & & \\
\hline $\begin{array}{l}\text { Schnitzler } \\
\text { syndrome }\end{array}$ & $\begin{array}{l}\text { NLRP3 V198M SNP in a single } \\
\text { patient, to date not in others }\end{array}$ & & $\begin{array}{l}\text { Inflammasome: increased IL-1 } \beta \\
\text { activation upon stimulation with LPS }\end{array}$ & \\
\hline
\end{tabular}

\section{Atopic Dermatitis}

Atopic dermatitis (AD) is a common chronic inflammatory skin disease that mainly affects children and is characterized by pruritus, eczematous lesions and xerosis. $\mathrm{AD}$ is associated with skin barrier abnormalities and a Th2 immune response [13]. AD lesions display lower levels of AMPs than psoriatic plaques $[35,36]$, and are often infected with Staphylococcus aureus, which is associated with AD flares and severity $[37,38]$. Herpes simplex virus (HSV) infections can also exacerbate AD and Candida species often colonizes atopic skin [37]. Defects in the innate immune system were hypothesized to predispose to $\mathrm{AD}$ development and to colonization with these pathogens. Hence, differences in PRR expression 
and function became research targets. S. aureus-diacylated lipoproteins were shown to induce expression of thymic stromal lymphopoietin (TSLP), which is highly expressed by keratinocytes in skin lesions of patients with AD. This process required signaling of the TLR2/TLR6 heterodimer and was enhanced by Th2 cytokines [39]. The role of TLR2 in AD is controversial, as is the case in other diseases. One study reported the association of the TLR2 A-16934T promoter polymorphism with severe $A D$, which did not affect TLR2 mRNA expression and resulted in decreased TLR2-induced IL-6, but not TNF- $\alpha$ production [40]. In one population the TLR2 R753Q polymorphism was associated with $\mathrm{AD}$ disease severity and increased colonization with S. aureus [41]. Previously, this polymorphism had been implicated in $S$. aureus infections [42]. The TLR2 R753Q polymorphism led to decreased cell surface expression of TLR2 in CD3/CD28activated CD4+ T cells, and impaired TLR2-mediated IL-8 secretion by monocytes [43]. In other populations, no associations between TLR1, TLR2, TLR4 and TLR6 polymorphisms and AD were found $[44,45]$. The data on TLR2 protein expression levels in AD lesions are also conflicting, since one study reported no difference with normal skin [16], whereas another study reported decreased TLR2 and increased TLR1 expression in AD lesions [46]. In this study, TLR4 and TLR9 protein expression levels were similar in $\mathrm{AD}$ lesions and normal skin [46]. The C-1237T polymorphism in the TLR9 promoter was significantly associated with $\mathrm{AD}$ in a subgroup of patients, and resulted in significantly higher promoter activity. This association was not seen in a case-control cohort in the same study, so it may only apply to some cases of $\mathrm{AD}$ [47]. One genetic study revealed an association of NOD1 polymorphisms with AD [48], but in other studies, genetic associations of AD with NOD1, NOD2 or NLRP12 were only slightly significant, which renders the pathophysiological implications questionable $[49,50]$.

A comprehensive study on epidermal PRR mRNA expression showed that expression of the majority of PRRs was similar in psoriasis, $\mathrm{AD}$ and normal skin. In $\mathrm{AD}$, dectin-1 was upregulated 6-fold and MRC1 10-fold [15]. Progenitor-derived mast cells from AD patients were shown to display lower dectin-1 expression, but the implications are yet to be determined [51].

\section{Allergic Contact Dermatitis}

Allergic contact dermatitis (ACD) is a type IV-delayed hypersensitivity reaction in the skin typically after sensitization by haptens. In mice, the concomitant absence of Tlr2 and Tlr4 prevented the induction of ACD to 2,4,6-trinitro-1-chlorobenzene (TNCB). Also, in Tlr4/IL12R $\beta 2$ double knockout mice, dendritic cell (DC)-mediated sensitization, generation of effector $\mathrm{T}$ cells, and the subsequent contact hypersensitivity response to TNCB, oxazolone, and fluorescein isothiocyanate were absent. This was not the case in TLR4 or IL-12 single knockout mice [52]. Epicutaneous immunization with protein antigen is applied as desensitization because it induces suppression of subsequent $\mathrm{T}$ cell-dependent contact hypersensitivity reactions after active immunization. Ptak et al. [53] found that this suppression can be reversed by crude bacterial components and purified TLR2, TLR3, TLR4, and TLR9 ligands. Also, the effect of TLR4 ligand LPS was not observed in Tlr4 mutant $\mathrm{C} 3 \mathrm{H} / \mathrm{HeJ}$ mice, which indicates that this effect was dependent upon intact TLR4 signaling. The inflammatory response in nickel ACD was shown to be TLR4 dependent. Interestingly, mouse Tlr4 could not generate this response, but transgenic expression of human TLR4 in TLR4-deficient mice allowed efficient sensitization to nickel and elicitation of ACD [54].

Watanabe et al. [55] showed involvement of the inflammasome in ACD. In primary human keratinocytes, TNCB and SDS induced IL-1 $\beta$ activation in a caspase-1dependent manner. In Asc and Nlrp3 knockout mice, TNCB-induced ACD was reduced.

NLRP12 is one of the latest identified NLRs. In two models of ACD (oxazolone and FITC), Nlrp12-deficient mice exhibited attenuated inflammatory responses. Nlrp12 knockout DCs were less capable of migrating to draining lymph nodes, and both Nlrp12 knockout DCs and neutrophils failed to respond to chemokines in vitro [56].

Primary Skin Disorders with Speculative Associations with PRRs

In other skin disorders, the evidence for a role of PRRs is still more speculative, although it may have important implications. We will mention three examples of these.

\section{Rosacea}

Rosacea is a common skin disease that is characterized by facial inflammation, abnormal vascular dilatation and proliferation, and formation of granulomas. Symptoms are exacerbated by external triggers, such as UV light, heat, and a variety of microbes. TLR2 stimulation induced expression of kallikrein 5, a critical protease involved in the pathogenesis of rosacea, since it processes cathelicidin [16]. The increased TLR2 expression in rosacea may cause increased susceptibility to pathogen- and 
damage-associated molecular patterns (PAMPs and DAMPs) that trigger disease [16].

\section{Vitiligo}

Vitiligo is an autoimmune disease characterized by the destruction of melanocytes in the epidermis, resulting in depigmented maculae. It is associated with several other autoimmune disorders including autoimmune thyroid disease, rheumatoid arthritis, systemic lupus erythematosus (SLE), and diabetes [57]. NLRP1 genetic variants have been associated with vitiligo [57-59], which is interesting from a pathophysiological point of view, since NLRP1 is part of an inflammasome that activates IL-1 $\beta$ and can result in apoptosis. The functional aspects require further investigation.

\section{Stevens-Johnson Syndrome}

Stevens-Johnson syndrome and the related toxic epidermal necrolysis are severe acute-onset mucocutaneous disorders that can be induced by drugs or pathogens. In Japanese patients, TLR3 polymorphisms were associated with Stevens-Johnson syndrome and toxic epidermal necrolysis [60], while in another population TLR9 polymorphisms were not [61].

\section{PRRs in Systemic Inflammatory Disorders with Skin Manifestations}

PRRs are implicated in many systemic disorders, such as the autoinflammatory syndromes, which are characterized by a predisposition towards excessive innate immune activation, often affecting the skin [62]. Several autoinflammatory diseases somehow affect PRR signaling pathways, but in this review we chose to discuss those that are directly linked to PRRs. We will also discuss examples of multifactorial diseases in which PRRs were implicated, as listed in table 1 .

\section{Monogenic Disorders Directly Linked to a Mutation in} a PRR Gene

Cryopyrin-Associated Periodic Syndrome

CAPS refers to a spectrum of autoinflammatory diseases, previously known as familial cold associated periodic syndrome, Muckle-Wells syndrome, and the debilitating chronic infantile neurologic, cutaneous, articular syndrome. The latter was also known as neonatalonset multisystem inflammatory disease $[1,2]$. CAPS is clinically characterized by urticarial-like skin rashes which may be cold-induced, recurrent fevers, arthralgia

PRRs in Immune Disorders Affecting the Skin or arthritis, ocular symptoms, sometimes amyloidosis, and, in severely affected patients, severe neurological symptoms [63]. These diseases were collectively classified as CAPS upon recognition that all three were caused by heterozygous mutations in NLRP3, previously referred to as NALP3 or cryopyrin $[64,65]$. These are regarded as gain of function mutations, resulting in a hyperactive or constitutively active inflammasome, leading to systemic IL-1 $\beta$-induced inflammation. Monocytes and macrophages from Muckle-Wells syndrome patients display a basal secretion of mature IL-1 $\beta$ in the absence of any external stimulus [66]. Together, these data formed the rationale for trials with IL-1 blocking therapies. Indeed, the IL-1 receptor antagonist anakinra, the IL-1 receptor-Fc fusion protein rilonacept, and the human IgG1 anti-IL$1 \beta$ monoclonal antibody canakinumab are all successful in preventing inflammation in CAPS [2, 67-69].

NLRP12-Associated Periodic Syndrome

A very rare hereditary periodic fever syndrome results from mutations in the NLRP12 gene, and manifests with mainly cold-induced recurrent fevers, arthralgia, and in some cases urticarial rashes or abdominal pain [70-72]. The pathophysiology is not completely clear yet. NLRP12 was previously shown to inhibit nuclear factor- $\kappa \mathrm{B}$ (NF$\kappa \mathrm{B})$ signaling [73], and in some of the NLRP12 mutations a clear reduction of these inhibitory properties could be found, in keeping with a loss of function [70], but this was not true in all cases [74]. In another family, monocytes produced more IL- $1 \beta$ and reactive oxygen species upon stimulation with PAMPs [71]. Altogether, NLRP12 mutations cause an autoinflammatory syndrome through increased NF- $\kappa \mathrm{B}$ and/or IL-1 $\beta$ signaling.

\section{Blau Syndrome}

Blau syndrome, also known as early-onset sarcoidosis, is a rare autosomal dominant disorder which is characterized by granulomatous arthritis, uveitis and skin rash [75]. Various mutations in the NOD2 gene were found in patients with Blau syndrome, and all mutations were associated with constitutive activation of the transcription factor NF- $\kappa \mathrm{B}$ [75]. These mutations confer a gain of function to NOD2, while Crohn's disease-associated NOD2 variants impair NF- $\kappa$ B activation [76, 77].

Systemic Immune Disorders in Which a Role of PRRs Is Suspected

Gout and Pseudogout

Monosodium urate and calcium pyrophosphate dihydrate crystals were long known to cause arthritis in gout 
and pseudogout, respectively. In the so-called tophi, uric acid depositions induce inflammation in the skin. Both monosodium urate and calcium pyrophosphate dihydrate crystals were shown to be able to activate the NLRP3 inflammasome in vitro, provided there was costimulation with LPS, resulting in excessive IL- $1 \beta$ production [78]. The authors showed that macrophages from mice deficient in various components of the inflammasome, such as pro-caspase-1, ASC or NLRP3, did not respond to injection of urate crystals. The excessive production of IL-1 $\beta$ provides a rationale for IL-1 $\beta$ blocking therapies. Indeed, anakinra and rilonacept proved highly effective in clinical trials in gout patients $[79,80]$.

\section{Behçet's Disease}

Behçet's disease (BD) is a multisystem disease characterized by recurrent oral and genital ulcers, relapsing uveitis, and articular, neurologic, vascular, intestinal and pulmonary manifestations. Several groups studied NOD2 polymorphisms in $\mathrm{BD}$ patients, but found no association [81-83]. SNP analyses of TLR2, TLR4, CD14 and TLR9 in BD patients was also negative [84-88]. However, the S180L polymorphism in Toll/interleukin receptor 1 domain-containing adaptor protein (TIRAP), a protein involved in TLR2 and TLR4 signaling, was significantly associated with BD in UK, but not Middle Eastern, patients [86]. Also, a TLR4 variant was significantly more prevalent in HLA-B51-positive, but not HLA-B51-negative BD patients, compared with healthy control participants, which suggests a synergistic increase in susceptibility of $\mathrm{BD}$ in this population [89]. Thus, most genetic studies on PRRs in BD showed no association.

Systemic Lupus Erythematosus

SLE is predominantly regarded as a disorder of the adaptive immune system, but recent studies point towards a concomitant role of innate immune responses [90]. In murine SLE models, autoantibodies bind DNA or chromatin released from dying cells, forming complexes that can stimulate IFN- $\alpha$ production by DCs via TLR9 [91-94]. In addition, TLR9/MyD88 (myeloid differentiation factor 88) signaling is required for class switching to pathogenic IgG2a and $2 \mathrm{~b}$ autoantibodies in autoreactive $\mathrm{B}$ cells in SLE, resulting in a pathogenic loop [95]. The role of TLR9 is controversial, however, since others found that TLR9 knockdown resulted in exacerbation of autoimmunity rather than reduction [96]. Moreover, TLR9 was found to regulate TLR7- and MyD88-dependent autoantibody production and disease in a murine SLE model [97]. Possibly, differences between mouse strains account for these discrepancies. TLR9 polymorphisms were associated with lupus nephritis in a Chinese Han population, but the functional consequences of the polymorphisms are unclear [98]. Patients with active SLE displayed an increased number of TLR9-positive B cells, which correlated with elevated titers of autoantibodies against dsDNA. In vitro, serum from patients with SLE upregulated expression of TLR9 on plasma cells [99]. Tian et al. [100] showed that B cells and pDCs can be activated by immune complexes that contain DNA and high mobility group box (HMGB)-1 in a TLR9- and MyD88-dependent manner involving RAGE (receptor for advanced glycation end products). HMGB1 is also recognized by TLR2 and TLR4 [101]. In the sera of SLE patients, HMGB1 and anti-HMGB1 antibodies are often found [102], as are HMGB1-containing nucleosomes [103]. These HMGB1containing nucleosomes stimulated the production of proinflammatory cytokines in macrophages, and induced autoantibody production in BALB/c mice, both in a TLR2-dependent manner [103].

Activation of TLR7 and TLR8 by RNA and RNA containing immune complexes is also implicated in the pathogenesis of SLE [91, 92, 104, 105]. TLR7 and TLR8 are encoded on the $\mathrm{X}$ chromosome, which is intriguing since $90 \%$ of SLE cases occur in women. Hypothetically, a copy number increase of the TLR7 or TLR 8 genes could account for this predominance. Indeed, overexpression of TLR7 triggered autoimmune responses in mice and transgenic cell lines [106]. In PBMCs (the peripheral blood mononuclear cells) of patients with SLE, mRNA expression levels of TLR2, TLR7 and TLR9 were elevated, whereas TLR3, TLR4, TLR5 and TLR8 remained the same [107]. A TLR5 stop codon polymorphism abrogating TLR5 function was found to be associated with resistance to SLE [108]. Polymorphisms of some, but not all investigated heat shock protein 70 (HSP70) genes were associated with SLE $[109,110]$. Some studies suggest HSP70 is an endogenous TLR2 and TLR4 ligand [111, 112]. These associations are controversial, however, since some argue that contaminating PAMPs are responsible for the reported in vitro cytokine effects of HSPs, as highly purified HSPs do not show any cytokine effects [113].

TLR3, which recognizes dsRNA, is absent in B cells, but its activation on glomerular mesangial cells and antigen-presenting cells was shown to aggravate lupus nephritis in a mouse model [114]. However, TLR3 costimulation did not influence TLR7-induced complex glomerulonephritis in this mouse model [104]. The S180L polymorphism in the TLR2 and TLR4 pathway adaptor 
protein TIRAP was shown to decrease susceptibility to SLE in a Colombian population [115].

The majority of studies investigated the role of TLRs in SLE, but other PRRs may well be involved too. Kimkong et al. [116] found increased mRNA expression levels of IFI16 and AIM2 in PBMCs of SLE patients. Since these are cytosolic dsDNA receptors, they may well be involved in the immune reactions against host-derived DNA.

\section{Graft-versus-Host Disease}

Graft-versus-host disease (GVHD) occurs when donor cells from a bone marrow transplant attack healthy tissues of the host. The adaptive immune system is thought to be the main culprit, but recent findings implicate the host innate immune system as well. In the case of intestinal GVHD, microbiota may modulate innate immune response via PRRs [117]. For example, in murine experimental GVHD models, Tlr9 deficiency in the host but not the donor reduced intestinal immunopathology and GVHD-related mortality. GVHD was also reduced in mice upon treatment with synthetic inhibitory oligodeoxynucleotide (iODN) that blocks TLR9 signaling. However, it is not clear whether TLR9 inhibition impairs the graft-versus-tumor response too, which would be highly undesirable [116]. No increased GVHD was seen in recipient mice deficient in the crucial TLR adaptor proteins Myd88 (myeloid differentiation factor 88) or Trif (Toll-interleukin 1 receptor-domain-containing adapterinducing IFN- $\beta$ ). Recipient Tlr2 deficiency did not affect GVHD outcome in mice. Recipient Tlr4 deficiency did not affect GVHD in two murine studies, and more severe GVHD was seen in another. Donor Tlr4 deficiency did not affect GVHD in one murine study, but decreased GVHD severity in two others, while graft-versus-leukemia activity was preserved in one [117]. NOD2 polymorphisms were associated with GVHD in human transplant recipients $[118,119]$. In mice models, Nod2-deficient transplant recipients developed more severe GVHD, which was suggested to be caused by an increased activation status of DCs. NOD2 may therefore inhibit DC activation. Nod2 knockout in donor mice did not affect GVHD [120].

\section{Systemic Immune Disorders in Which a Role of PRRs}

Is Speculative

Sarcoidosis

Sarcoidosis is characterized by granulomas affecting multiple organs. In one study, severe pulmonary sarcoidosis was associated with NOD2 polymorphisms [121], but no NOD2 association was found in sarcoidosis in gen-

PRRs in Immune Disorders Affecting the Skin eral [122]. In a Japanese population, an association between NOD1 gene polymorphisms and sarcoidosis susceptibility was found. The polymorphism was associated with reduced NOD1 expression and impaired NF- $\kappa$ B activation upon infection with Propionibacterium acnes [123].

\section{Schnitzler Syndrome}

Schnitzler syndrome is an acquired syndrome characterized by chronic urticaria paraproteinemia with signs and symptoms of systemic inflammation, such as arthralgia and recurrent fever [124]. It has similarities to the hereditary syndrome CAPS (see above), and IL-1 $\beta$ has been shown to be a central mediator of this disorder as well $[125,126]$. The exact pathophysiology is unknown. In 1 patient, the common variant V198M was found in the NLRP3 gene [127], but not in others [128]. The success of IL-1 inhibition as treatment in Schnitzler syndrome supports the suspicion of a role of PRRs in the pathophysiology of this rare syndrome $[126,128,129]$.

\section{PRRs as Therapeutic Target in Immune Disorders}

In view of their potential detrimental role in a multitude of immune disorders, inhibition of PRR pathways may be a promising therapeutic approach. Conversely, PRR triggering has become a prominent topic in research on the immunomodulation of tumors, which we will discuss separately below.

\section{Immunomodulation of PRRs by Established}

Treatments in Immune Disorders

Calcineurin Inhibitors

Calcineurin inhibitors, such as cyclosporin A, tacrolimus and pimecrolimus, are used in the treatment of psoriasis and $\mathrm{AD}$, and to prevent rejection in transplant patients. These agents suppress T cell-mediated immune responses, especially the production of proinflammatory cytokines in T cells, but recently evidence emerged that these calcineurin inhibitors also directly affect PRRs. In an immunohistochemical analysis of AD lesions, tacrolimus was found to reverse the increased TLR1 and decreased TLR2 expression levels [46]. In normal human epidermal keratinocytes, pimecrolimus enhanced TLR2/ TLR6-induced expression of antimicrobial peptides. Interestingly, pimecrolimus also increased the functional capacity of keratinocytes to inhibit growth of $S$. aureus, which often colonizes the skin of $\mathrm{AD}$ patients and causes superinfections of AD lesions [130].

J Innate Immun 2012;4:225-240 


\section{Chloroquine}

The antimalarial drugs chloroquine and hydroxychloroquine have been applied as therapeutic agents for SLE for many years, although the mechanism of action is unclear. A direct role of modulation of PRRs is suggested by studies which show that they inhibit stimulation of TLR3, TLR8 and TLR9, presumably by direct binding to nucleic acids, thereby masking the TLR-binding epitopes [131, 132].

\section{Immunomodulation of PRRs in Experimental Models} of Immune Disorders

TLR9 Agonists

Not only inhibition, but also stimulation of PRRs might be of benefit in a therapeutic setting. Applications of TLR9 agonists, also referred to as CpG oligodeoxynucleotides (ODN), are investigated in mouse models of allergy, since the Th1-biased immune response upon TLR9 activation may improve desensitization strategies in allergy treatment. Indeed, $\mathrm{CpG}$ ODN inhibited the Th2 response in allergic mice, preventing inflammatory disease manifestations. In human clinical trials with a conjugate of CpG ODN and part of the ragweed allergen as an allergy vaccine, selective redirection of the allergic Th2 response towards a Th1 response, and reduced allergic symptoms were observed [131]. Even though these studies were mainly on murine asthma models, they could have implications for the treatment of allergic cutaneous diseases.

Of note, $\mathrm{CpG}$ ODN were also found to accelerate wound healing in mice and rhesus macaques, which could have therapeutic implications for chronic wounds in humans $[133,134]$.

\section{Combined TLR7/TLR9 Inhibition}

TLR7 signaling is involved in the pathophysiology of SLE, while results on the role of TLR9 are conflicting. A specific inhibitor of TLR7 and TLR9, immunoregulatory sequence (IRS) 954, was shown to inhibit the induction of IFN- $\alpha$ by human pDCs upon stimulation with DNA and RNA viruses and isolated immune complexes from SLE patients [91]. In SLE-prone mice, IRS 954 prevented progression of disease [135]. Recently, TLR7 and TLR9 signaling was shown to hamper glucocorticoid efficacy in SLE. Triggering of TLR7 and TLR9 by nucleic acid-containing immune complexes or by synthetic ligands enhanced survival of IFN- $\alpha$-producing pDCs [136]. The role of TLR9 is controversial, however, since others found that TLR9 knockdown resulted in exacerbation of autoimmunity rather than reduction [96].

\section{PRRs as Therapeutic Target in Tumors}

\section{Antitumor Immunomodulation of PRRs by}

\section{Established Treatments}

Imidazoquinolines

The prototype of a PRR-targeting therapy is imiquimod, an imidazoquinoline compound which is a synthetic agonist of TLR7 and to a lesser extent TLR8 [137, 138]. In contrast, imidazoquinolines were found to inhibit TLR3 and TLR9 signaling [132]. Imiquimod has potent antitumor and antiviral properties and is an approved topical therapy for superficial basal cell carcinoma, actinic keratosis and genital warts $[139,140]$. There are multiple off-label indications for imiquimod, including HSV infections, verruca vulgaris, molluscum contagiosum, keloids, squamous cell carcinoma, Bowen's disease, lentigo maligna, cutaneous T cell lymphoma, Kaposi's sarcoma, and Paget's disease [141, 142]. Imiquimod induces the production of several proinflammatory cytokines, stimulates $\mathrm{T}$ cell responses, and instigates the migration of Langerhans cells and pDCs to the lymph nodes [138, 143-145]. Moreover, at higher concentrations imiquimod induced apoptosis in basal cell carcinomas and melanoma metastases, but it is not clear whether this is a direct or indirect effect on the tumor cells [138]. Resiquimod is a more potent TLR7- and TLR8-activating imidazoquinoline which was reported to be effective in the treatment of actinic keratosis [146] and genital HSV-2 infections $[147,148]$. Because of its immunomodulating properties, imiquimod has been tested as an adjuvant in antitumor vaccines. In a murine model, topical imiquimod significantly enhanced the protective antitumor effects of a live, recombinant $L i s t e r i a$ vaccine against melanoma [149]. In melanoma patients, the combination of a NY-ESO-1 vaccine with topical imiquimod elicited both humoral and cellular responses in a significant fraction of patients, but the additive effect of imiquimod was unclear since a vaccine-only control arm was lacking [150]. The downside of immunomodulation by TLR7 agonists is excessive immune responses. Indeed, imiquimod often induces local skin inflammation at the application site, but it was also reported to aggravate psoriatic lesions and even to induce de novo psoriasis [21-24].

\section{Investigational Antitumor Immunomodulation of}

PRRs

Loxoribine

Loxoribine, another TLR7 agonist, enhances the production of IFN, activates NK cells and B cells [151], and was recently found to induce maturation of human 
monocyte-derived DCs and to stimulate their Th1- and Th17-polarizing capability [152]. Hence, loxoribine has been under investigation for antiviral and antitumor properties [153], although not as intensively as imiquimod.

\section{TLR9 Agonists}

CpG ODN directly induce the activation and maturation of pDCs and enhance differentiation of B cells into antibody-secreting plasma cells [131]. As an adjuvant, CpG ODN were shown to induce strong CD4+ and $\mathrm{CD} 8+\mathrm{T}$ cell responses and rapid production of antigenspecific antibodies to many types of antigen [154]. They are therefore considered as promising adjuvants in anticancer vaccines, e.g. in the treatment of melanoma [131, 155-157]. In mice with cutaneous melanoma, combination therapy of topical CpG ODN with systemic dacarbazine inhibited tumor growth significantly more than with monotherapy with either agent [156]. Importantly, TLR9 expression patterns differ between mice and humans, and CpG DNA are less stimulating in humans than in mice; therefore these results cannot automatically be extrapolated to humans [154]. In patient trials, monotherapy with the TLR9 agonist PF-3512676 induced immune responses, but for optimal clinical efficacy CpG ODN are currently under investigation as antimelanoma vaccine adjuvants [155].

\section{Conclusion}

PRRs have been implicated in the pathophysiology of multiple immune disorders that affect the skin. Once evolved to protect us from pathogens, at which they are quite successful, they can become detrimental if signaling is excessive. Indications that PRRs are involved in the pathophysiology of multifactorial immune disorders are mainly based on genetic association studies and murine knockout models. Comprehensive endogenous expression analyses and functional studies are urgently needed to determine their actual contribution to the pathophysiology. This will also lead to more targeted therapies, since immunomodulation of PRRs seems a promising therapeutic approach to various immune disorders and malignancies.

\section{Acknowledgments}

H.D.K. is supported by an AGIKO stipend from the Netherlands Organization for Health Research and Development, A.S. by a VIDI grant from the Netherlands Organization for Health Research and Development, and P.L.J.M.Z. by a grant from the Dutch Ministry of Economic Affairs (PID082025).

\section{Disclosure Statement}

The authors state no conflict of interest.

\section{References}

$\checkmark 1$ Hoffman HM, Wanderer AA: Inflammasome and IL-1beta-mediated disorders. Curr Allergy Asthma Rep 2010;10:229-235.

-2 Lachmann HJ, Quartier P, So A, Hawkins PN: The emerging role of interleukin-1beta in autoinflammatory diseases. Arthritis Rheum 2011;63:314-324.

-3 Masters SL, Dunne A, Subramanian SL, Hull RL, Tannahill GM, Sharp FA, Becker C, Franchi L, Yoshihara E, Chen Z, Mullooly N, Mielke LA, Harris J, Coll RC, Mills KH, Mok KH, Newsholme P, Nunez G, Yodoi J, Kahn SE, Lavelle EC, O'Neill LA: Activation of the NLRP3 inflammasome by islet amyloid polypeptide provides a mechanism for enhanced IL-1beta in type 2 diabetes. Nat Immunol 2010;11:897-904.

44 Masters SL, Latz E, O'Neill LA: The inflammasome in atherosclerosis and type 2 diabetes. Sci Transl Med 2011;3:81ps17.

5 Menu P, Vince JE: The NLRP3 inflammasome in health and disease: the good, the bad and the ugly. Clin Exp Immunol 2011;166: $1-15$.
6 Kawai T, Akira S: The roles of TLRs, RLRs and NLRs in pathogen recognition. Int Immunol 2009;21:317-337.

7 Carneiro LA, Magalhaes JG, Tattoli I, Philpott DJ, Travassos LH: Nod-like proteins in inflammation and disease. J Pathol 2008; 214:136-148.

-8 Burckstummer T, Baumann C, Bluml S, Dixit E, Durnberger G, Jahn H, Planyavsky M, Bilban M, Colinge J, Bennett KL, SupertiFurga G: An orthogonal proteomic-genomic screen identifies AIM2 as a cytoplasmic DNA sensor for the inflammasome. Nat Immunol 2009;10:266-272.

-9 Fernandes-Alnemri T, Yu JW, Datta P, Wu J, Alnemri ES: AIM2 activates the inflammasome and cell death in response to cytoplasmic DNA. Nature 2009;458:509-513.

10 Hornung V, Ablasser A, Charrel-Dennis M, Bauernfeind F, Horvath G, Caffrey DR, Latz E, Fitzgerald KA: AIM2 recognizes cytosolic dsDNA and forms a caspase-1-activating inflammasome with ASC. Nature 2009;458: 514-518.
Unterholzner L, Keating SE, Baran M, Horan KA, Jensen SB, Sharma S, Sirois CM, Jin T, Latz E, Xiao TS, Fitzgerald KA, Paludan SR, Bowie AG: IFI16 is an innate immune sensor for intracellular DNA. Nat Immunol 2010; 11:997-1004.

12 Poeck H, Bscheider M, Gross O, Finger K, Roth S, Rebsamen M, Hannesschlager N, Schlee M, Rothenfusser S, Barchet W, Kato $\mathrm{H}$, Akira S, Inoue S, Endres S, Peschel C, Hartmann G, Hornung V, Ruland J: Recognition of RNA virus by RIG-I results in activation of CARD9 and inflammasome signaling for interleukin 1 beta production. Nat Immunol 2010;11:63-69.

13 Guttman-Yassky E, Nograles KE, Krueger JG: Contrasting pathogenesis of atopic dermatitis and psoriasis. I. Clinical and pathologic concepts. J Allergy Clin Immunol 2011; 127:1110-1118.

14 Nestle FO, Kaplan DH, Barker J: Psoriasis. N Engl J Med 2009;361:496-509. 
$\checkmark 15$ de Koning HD, Rodijk-Olthuis D, Van Vlijmen-Willems IM, Joosten LA, Netea MG, Schalkwijk J, Zeeuwen PL: A comprehensive analysis of pattern recognition receptors in normal and inflamed human epidermis: upregulation of dectin-1 in psoriasis. J Invest Dermatol 2010;130:2611-2620.

- 16 Yamasaki K, Kanada K, Macleod DT, Borkowski AW, Morizane S, Nakatsuji T, Cogen AL, Gallo RL: TLR2 expression is increased in rosacea and stimulates enhanced serine protease production by keratinocytes. J Invest Dermatol 2011;131:688-697.

-17 Baker BS, Ovigne JM, Powles AV, Corcoran S, Fry L: Normal keratinocytes express Tolllike receptors (TLRs) 1,2 and 5: modulation of TLR expression in chronic plaque psoriasis. Br J Dermatol 2003;148:670-679.

- 18 Begon E, Michel L, Flageul B, Beaudoin I, Jean-Louis F, Bachelez H, Dubertret L, Musette P: Expression, subcellular localization and cytokinic modulation of Toll-like receptors (TLRs) in normal human keratinocytes: TLR2 up-regulation in psoriatic skin. Eur J Dermatol 2007;17:497-506.

19 Miller LS, Sorensen OE, Liu PT, Jalian HR, Eshtiaghpour D, Behmanesh BE, Chung W, Starner TD, Kim J, Sieling PA, Ganz T, Modlin RL: TGF-alpha regulates TLR expression and function on epidermal keratinocytes. J Immunol 2005;174:6137-6143.

-20 Kollisch G, Kalali BN, Voelcker V, Wallich R, Behrendt H, Ring J, Bauer S, Jakob T, Mempel M, Ollert M: Various members of the Toll-like receptor family contribute to the innate immune response of human epidermal keratinocytes. Immunology 2005;114:531541.

-21 Fanti PA, Dika E, Vaccari S, Miscial C, Varotti C: Generalized psoriasis induced by topical treatment of actinic keratosis with imiquimod. Int J Dermatol 2006;45:14641465.

22 Patel U, Mark NM, Machler BC, Levine VJ: Imiquimod 5\% cream induced psoriasis: a case report, summary of the literature and mechanism. Br J Dermatol 2011;164:670672.

-23 Wu JK, Siller G, Strutton G: Psoriasis induced by topical imiquimod. Australas J Dermatol 2004;45:47-50.

24 Rajan N, Langtry JA: Generalized exacerbation of psoriasis associated with imiquimod cream treatment of superficial basal cell carcinomas. Clin Exp Dermatol 2006;31:140141.

25 Nestle FO, Conrad C, Tun-Kyi A, Homey B, Gombert M, Boyman O, Burg G, Liu YJ, Gilliet M: Plasmacytoid predendritic cells initiate psoriasis through interferon-alpha production. J Exp Med 2005;202:135-143.

-26 Garcia-Lora E, Tercedor J, Massare E, LopezNevot MA, Skiljo M, Garcia-Mellado V: Interferon-induced psoriasis in a patient with chronic hepatitis C. Dermatology 1993;187: 280.
27 Ladoyanni E, Nambi R: Psoriasis exacerbated by interferon-alpha in a patient with chronic myeloid leukemia. J Drugs Dermatol 2005;4:221-222.

28 Kowalzick L: Psoriasis flare caused by recombinant interferon beta injections. J Am Acad Dermatol 1997;36:501.

29 van der Fits L, Mourits S, Voerman JS, Kant M, Boon L, Laman JD, Cornelissen F, Mus AM, Florencia E, Prens EP, Lubberts E: Imiquimod-induced psoriasis-like skin inflammation in mice is mediated via the IL-23/IL17 axis. J Immunol 2009; 182:5836-5845.

30 Prens EP, Kant M, van Dijk G., van der Wel LI, Mourits S, van der Fits L: IFN-alpha enhances poly-IC responses in human keratinocytes by inducing expression of cytosolic innate RNA receptors: relevance for psoriasis. J Invest Dermatol 2008;128:932-938.

31 Zhu K, Yin X, Tang X, Zhang F, Yang S, Zhang X: Meta-analysis of NOD2/CARD15 polymorphisms with psoriasis and psoriatic arthritis. Rheumatol Int 2011, E-pub ahead of print.

32 Netea MG, Marodi L: Innate immune mechanisms for recognition and uptake of Candida species. Trends Immunol 2010;31:346353.

33 Lande R, Gregorio J, Facchinetti V, Chatterjee B, Wang YH, Homey B, Cao W, Wang YH, Su B, Nestle FO, Zal T, Mellman I, Schroder JM, Liu YJ, Gilliet M: Plasmacytoid dendritic cells sense self-DNA coupled with antimicrobial peptide. Nature 2007;449:564-569.

34 Dombrowski Y, Peric M, Koglin S, Kammerbauer C, Goss C, Anz D, Simanski M, Glaser R, Harder J, Hornung V, Gallo RL, Ruzicka T, Besch R, Schauber J: Cytosolic DNA triggers inflammasome activation in keratinocytes in psoriatic lesions. Sci Transl Med 2011;3:82ra38.

- 35 de Jongh GJ, Zeeuwen PL, Kucharekova M, Pfundt R, van der Valk, Blokx W, Dogan A, Hiemstra PS, van de Kerkhof PC, Schalkwijk J: High expression levels of keratinocyte antimicrobial proteins in psoriasis compared with atopic dermatitis. J Invest Dermatol 2005;125:1163-1173.

36 Ong PY, Ohtake T, Brandt C, Strickland I, Boguniewicz M, Ganz T, Gallo RL, Leung DY: Endogenous antimicrobial peptides and skin infections in atopic dermatitis. N Engl J Med 2002;347:1151-1160.

37 Maintz L, Novak N: Modifications of the innate immune system in atopic dermatitis. J Innate Immun 2011;3:131-141.

38 Baker BS: The role of microorganisms in atopic dermatitis. Clin Exp Immunol 2006; 144:1-9.

39 Vu AT, Baba T, Chen X, Le TA, Kinoshita H, Xie Y, Kamijo S, Hiramatsu K, Ikeda S, Ogawa H, Okumura K, Takai T: Staphylococcus aureus membrane and diacylated lipopeptide induce thymic stromal lymphopoietin in keratinocytes through the Toll-like receptor 2-Toll-like receptor 6 pathway. J Allergy Clin Immunol 2010;126:985-993.
40 Oh DY, Schumann RR, Hamann L, Neumann K, Worm M, Heine G: Association of the toll-like receptor $2 \mathrm{~A}-16934 \mathrm{~T}$ promoter polymorphism with severe atopic dermatitis. Allergy 2009;64:1608-1615.

-41 Ahmad-Nejad P, Mrabet-Dahbi S, Breuer K, Klotz M, Werfel T, Herz U, Heeg K, Neumaier M, Renz H: The toll-like receptor 2 R753Q polymorphism defines a subgroup of patients with atopic dermatitis having severe phenotype. J Allergy Clin Immunol 2004; 113:565-567.

42 Lorenz E, Mira JP, Cornish KL, Arbour NC, Schwartz DA: A novel polymorphism in the toll-like receptor 2 gene and its potential association with staphylococcal infection. Infect Immun 2000;68:6398-6401.

43 Niebuhr M, Lutat C, Sigel S, Werfel T: Impaired TLR-2 expression and TLR-2-mediated cytokine secretion in macrophages from patients with atopic dermatitis. Allergy 2009;64:1580-1587.

44 Weidinger S, Novak N, Klopp N, Baurecht H, Wagenpfeil S, Rummler L, Ring J, Behrendt $\mathrm{H}$, Illig T: Lack of association between Tolllike receptor 2 and Toll-like receptor 4 polymorphisms and atopic eczema. J Allergy Clin Immunol 2006;118:277-279.

45 Hoffjan S, Stemmler S, Parwez Q, PetraschParwez E, Arinir U, Rohde G, ReinitzRademacher K, Schultze-Werninghaus G, Bufe A, Epplen JT: Evaluation of the toll-like receptor 6 Ser249Pro polymorphism in patients with asthma, atopic dermatitis and chronic obstructive pulmonary disease. BMC Med Genet 2005;6:34.

46 Antiga E, Volpi W, Torchia D, Fabbri P, Caproni $\mathrm{M}$ : Effects of tacrolimus ointment on Toll-like receptors in atopic dermatitis. Clin Exp Dermatol 2011;36:235-241

47 Novak N, Yu CF, Bussmann C, Maintz L, Peng WM, Hart J, Hagemann T, Diaz-Lacava A, Baurecht HJ, Klopp N, Wagenpfeil S, Behrendt $\mathrm{H}$, Bieber T, Ring J, Illig T, Weidinger S: Putative association of a TLR9 promoter polymorphism with atopic eczema. Allergy 2007;62:766-772.

-48 Weidinger S, Klopp N, Rummler L, Wagenpfeil S, Novak N, Baurecht HJ, Groer W, Darsow U, Heinrich J, Gauger A, Schafer T, Jakob T, Behrendt H, Wichmann HE, Ring J, Illig T: Association of NOD1 polymorphisms with atopic eczema and related phenotypes. J Allergy Clin Immunol 2005;116:177-184.

-49 Kabesch M, Peters W, Carr D, Leupold W, Weiland SK, von Mutius E: Association between polymorphisms in caspase recruitment domain containing protein 15 and allergy in two German populations. J Allergy Clin Immunol 2003;111:813-817.

50 Macaluso F, Nothnagel M, Parwez Q, Petrasch-Parwez E, Bechara FG, Epplen JT, Hoffjan S: Polymorphisms in NACHT-LRR (NLR) genes in atopic dermatitis. Exp Dermatol 2007;16:692-698. 
51 Ribbing C, Engblom C, Lappalainen J, Lindstedt K, Kovanen PT, Karlsson MA, Lundeberg L, Johansson C, Nilsson G, LunderiusAndersson C, Scheynius A: Mast cells generated from patients with atopic eczema have enhanced levels of granule mediators and an impaired Dectin-1 expression. Allergy 2011; 66:110-119.

-52 Martin SF, Dudda JC, Bachtanian E, Lembo A, Liller S, Durr C, Heimesaat MM, Bereswill S, Fejer G, Vassileva R, Jakob T, Freudenberg N, Termeer CC, Johner C, Galanos C, Freudenberg MA: Toll-like receptor and IL12 signaling control susceptibility to contact hypersensitivity. J Exp Med 2008;205:21512162.

-53 Ptak W, Bryniarski K, Ptak M, Majewska M, Gamian A, Lobo FM, Szczepanik M: Tolllike receptor ligands reverse suppression of contact hypersensitivity reactions induced by epicutaneous immunization with protein antigen. Int Arch Allergy Immunol 2006; 139:188-200.

- 54 Schmidt M, Raghavan B, Muller V, Vogl T, Fejer G, Tchaptchet S, Keck S, Kalis C, Nielsen PJ, Galanos C, Roth J, Skerra A, Martin SF, Freudenberg MA, Goebeler M: Crucial role for human Toll-like receptor 4 in the development of contact allergy to nickel. Nat Immunol 2010;11:814-819.

- 55 Watanabe H, Gaide O, Petrilli V, Martinon F, Contassot E, Roques S, Kummer JA, Tschopp J, French LE: Activation of the ILlbeta-processing inflammasome is involved in contact hypersensitivity. J Invest Dermatol 2007;127:1956-1963.

-56 Arthur JC, Lich JD, Ye Z, Allen IC, Gris D, Wilson JE, Schneider M, Roney KE, O'Connor BP, Moore CB, Morrison A, Sutterwala FS, Bertin J, Koller BH, Liu Z, Ting JP: Cutting edge: NLRP12 controls dendritic and myeloid cell migration to affect contact hypersensitivity. J Immunol 2010;185:45154519.

57 Jin Y, Mailloux CM, Gowan K, Riccardi SL, LaBerge G, Bennett DC, Fain PR, Spritz RA: NALP1 in vitiligo-associated multiple autoimmune disease. N Engl J Med 2007;356: $1216-1225$.

58 Alkhateeb A, Qarqaz F: Genetic association of NALP1 with generalized vitiligo in Jordanian Arabs. Arch Dermatol Res 2010;302: 631-634.

-59 Jin Y, Birlea SA, Fain PR, Spritz RA: Genetic variations in NALP1 are associated with generalized vitiligo in a Romanian population. J Invest Dermatol 2007;127:2558-2562.

-60 Ueta M, Sotozono C, Inatomi T, Kojima K, Tashiro K, Hamuro J, Kinoshita S: Toll-like receptor 3 gene polymorphisms in Japanese patients with Stevens-Johnson syndrome. $\mathrm{Br}$ J Ophthalmol 2007;91:962-965.
61 Turan H, Bulbul BE, Yakut T, Karkucak M, Tunali S, Saricaoglu H: Toll-like receptor 9 polymorphism in patients with erythema multiforme, Stevens-Johnson syndrome and Stevens Johnson syndrome/toxic epidermal necrolysis overlap syndrome. Bratisl Lek Listy 2011;112:260-263.

62 Masters SL, Simon A, Aksentijevich I, Kastner DL: Horror autoinflammaticus: the molecular pathophysiology of autoinflammatory disease $(*)$. Annu Rev Immunol 2009;27: 621-668.

63 Henderson C, Goldbach-Mansky R: Monogenic autoinflammatory diseases: new insights into clinical aspects and pathogenesis. Curr Opin Rheumatol 2010;22:567-578.

64 Aksentijevich I, Nowak M, Mallah M, Chae JJ, Watford WT, Hofmann SR, Stein L, Russo R, Goldsmith D, Dent P, Rosenberg HF, Austin F, Remmers EF, Balow JE Jr, Rosenzweig S, Komarow H, Shoham NG, Wood G, Jones J, Mangra N, Carrero H, Adams BS, Moore TL, Schikler K, Hoffman H, Lovell DJ, Lipnick R, Barron K, O’Shea JJ, Kastner DL, Goldbach-Mansky R: De novo CIAS1 mutations, cytokine activation, and evidence for genetic heterogeneity in patients with neonatal-onset multisystem inflammatory disease (NOMID): a new member of the expanding family of pyrin-associated autoinflammatory diseases. Arthritis Rheum 2002;46:3340 3348.

65 Hoffman HM, Mueller JL, Broide DH, Wanderer AA, Kolodner RD: Mutation of a new gene encoding a putative pyrin-like protein causes familial cold autoinflammatory syndrome and Muckle-Wells syndrome. Nat Genet 2001;29:301-305.

66 Agostini L, Martinon F, Burns K, McDermott MF, Hawkins PN, Tschopp J: NALP3 forms an IL-1beta-processing inflammasome with increased activity in MuckleWells autoinflammatory disorder. Immunity $2004 ; 20: 319-325$.

67 Hoffman HM, Rosengren S, Boyle DL, Cho JY, Nayar J, Mueller JL, Anderson JP, Wanderer AA, Firestein GS: Prevention of coldassociated acute inflammation in familial cold autoinflammatory syndrome by interleukin-1 receptor antagonist. Lancet 2004; 364:1779-1785.

68 Hoffman HM, Throne ML, Amar NJ, Sebai M, Kivitz AJ, Kavanaugh A, Weinstein SP, Belomestnov P, Yancopoulos GD, Stahl N, Mellis SJ: Efficacy and safety of rilonacept (interleukin-1 Trap) in patients with cryopyrin-associated periodic syndromes: results from two sequential placebo-controlled studies. Arthritis Rheum 2008;58:24432452.

69 Lachmann HJ, Kone-Paut I, KuemmerleDeschner JB, Leslie KS, Hachulla E, Quartier P, Gitton X, Widmer A, Patel N, Hawkins PN: Use of canakinumab in the cryopyrin-associated periodic syndrome. N Engl J Med 2009;360:2416-2425.
70 Jeru I, Duquesnoy P, Fernandes-Alnemri T, Cochet E, Yu JW, Lackmy-Port-Lis M, Grimprel E, Landman-Parker J, Hentgen V, Marlin S, McElreavey K, Sarkisian T, Grateau G, Alnemri ES, Amselem S: Mutations in NALP12 cause hereditary periodic fever syndromes. Proc Natl Acad Sci USA 2008;105: 1614-1619.

71 Borghini S, Tassi S, Chiesa S, Caroli F, Carta S, Caorsi R, Fiore M, Delfino L, Lasiglie D, Ferraris C, Traggiai E, Di Duca M, Santamaria G, D'Osualdo A, Tosca M, Martini A, Ceccherini I, Rubartelli A, Gattorno M: Clinical presentation and pathogenesis of cold-induced autoinflammatory disease in a family with recurrence of an NLRP12 mutation. Arthritis Rheum 2011;63:830-839.

72 Jeru I, Le Borgne G, Cochet E, Hayrapetyan H, Duquesnoy P, Grateau G, Morali A, Sarkisian T, Amselem S: Identification and functional consequences of a recurrent NLRP12 missense mutation in periodic fever syndromes. Arthritis Rheum 2011;63:14591464.

73 Lich JD, Williams KL, Moore CB, Arthur JC, Davis BK, Taxman DJ, Ting JP: Monarch-1 suppresses non-canonical NF-kappaB activation and p52-dependent chemokine expression in monocytes. J Immunol 2007; 178: $1256-1260$.

74 Jeru I, Hentgen V, Normand S, Duquesnoy P, Cochet E, Delwail A, Grateau G, Marlin S, Amselem S, Lecron JC: Role of interleukin1beta in NLRP12-associated autoinflammatory disorders and resistance to anti-interleukin-1 therapy. Arthritis Rheum 2011;63: 2142-2148.

75 Okafuji I, Nishikomori R, Kanazawa N, Kambe N, Fujisawa A, Yamazaki S, Saito M, Yoshioka T, Kawai T, Sakai H, Tanizaki H, Heike T, Miyachi Y, Nakahata T: Role of the NOD2 genotype in the clinical phenotype of Blau syndrome and early-onset sarcoidosis. Arthritis Rheum 2009;60:242-250.

76 Magalhaes JG, Sorbara MT, Girardin SE, Philpott DJ: What is new with Nods? Curr Opin Immunol 2011;23:29-34.

$\checkmark 77$ Chen G, Shaw MH, Kim YG, Nunez G: NOD-like receptors: role in innate immunity and inflammatory disease. Annu Rev Pathol 2009;4:365-398.

78 Martinon F, Petrilli V, Mayor A, Tardivel A, Tschopp J: Gout-associated uric acid crystals activate the NALP3 inflammasome. Nature 2006;440:237-241.

79 So A, De Smedt T, Revaz S, Tschopp J: A pilot study of IL-1 inhibition by anakinra in acute gout. Arthritis Res Ther 2007;9:R28.

$\checkmark 80$ Terkeltaub R, Sundy JS, Schumacher HR, Murphy F, Bookbinder S, Biedermann S, Wu $\mathrm{R}$, Mellis S, Radin A: The interleukin 1 inhibitor rilonacept in treatment of chronic gouty arthritis: results of a placebo-controlled, monosequence crossover, non-randomised, single-blind pilot study. Ann Rheum Dis 2009;68:1613-1617. 
-81 Ahmad T, Zhang L, Gogus F, Verity D, Wallace G, Madanat W, Fayyad F, James T, Neville M, Kanawati C, Fortune F, Celik A, Stanford M, Jewell DP, Marshall SE: CARD15 polymorphisms in Behcet's disease. Scand J Rheumatol 2005;34:233-237.

-82 Uyar FA, Saruhan-Direskeneli G, Gul A: Common Crohn's disease-predisposing variants of the CARD15/NOD2 gene are not associated with Behcet's disease in Turkey. Clin Exp Rheumatol 2004;22:S50-S52.

-83 Kappen JH, Wallace GR, Stolk L, Rivadeneira F, Uitterlinden AG, van Daele PL, Laman JD, Kuijpers RW, Baarsma GS, Stanford MR, Fortune F, Madanat W, van Hagen PM, van Laar JA: Low prevalence of NOD2 SNPs in Behcet's disease suggests protective association in Caucasians. Rheumatology (Oxford) 2009;48:1375-1377.

84 Bacanli A, Sallakci N, Yavuzer U, Alpsoy E, Yegin O: Toll-like receptor 2 Arg753Gln gene polymorphism in Turkish patients with Behcet's disease. Clin Exp Dermatol 2006;31: 699-701.

-85 Cosan F, Oku B, Cakiris A, Duymaz-Tozkir J, Mercanoglu F, Saruhan-Direskeneli G, Ustek D, Gul A: No association of the TLR2 gene Arg753Gln polymorphism with rheumatic heart disease and Behcet's disease. Clin Rheumatol 2009;28:1385-1388.

86 Durrani O, Banahan K, Sheedy FJ, McBride L, Ben-Chetrit E, Greiner K, Vaughan RW, Kondeatis E, Hamburger J, Fortune F, Stanford MR, Murray PI, O'Neill LA, Wallace GR: TIRAP Ser180Leu polymorphism is associated with Behcet's disease. Rheumatology (Oxford) 2011;50:1760-1765.

- 87 Ben Dhifallah I, Lachheb J, Houman H, Hamzaoui K: Toll-like-receptor gene polymorphisms in a Tunisian population with Behcet's disease. Clin Exp Rheumatol 2009; 27:S58-S62.

$\checkmark 88$ Boiardi L, Atzeni F, Casali B, Farnetti E, Nicoli D, Pipitone N, Catanoso MG, Olivieri I, Cantini F, Salvi F, La CR, Triolo G, Filippini D, Paolazzi G, Salvarani C: Toll-like receptor 4 (TLR4) gene polymorphisms in Italian patients with Behcet's disease. Clin Exp Rheumatol 2009;27:S43-S47.

-89 Horie Y, Meguro A, Ota M, Kitaichi N, Katsuyama Y, Takemoto Y, Namba K, Yoshida K, Song YW, Park KS, Lee EB, Inoko H, Mizuki N, Ohno S: Association of TLR4 polymorphisms with Behcet's disease in a Korean population. Rheumatology (Oxford) 2009; 48:638-642.

90 Drexler SK, Foxwell BM: The role of toll-like receptors in chronic inflammation. Int J Biochem Cell Biol 2010;42:506-518.

-91 Barrat FJ, Meeker T, Gregorio J, Chan JH, Uematsu S, Akira S, Chang B, Duramad O, Coffman RL: Nucleic acids of mammalian origin can act as endogenous ligands for Toll-like receptors and may promote systemic lupus erythematosus. J Exp Med 2005;202: 1131-1139.
\$2 Guiducci C, Tripodo C, Gong M, Sangaletti S, Colombo MP, Coffman RL, Barrat FJ: Autoimmune skin inflammation is dependent on plasmacytoid dendritic cell activation by nucleic acids via TLR7 and TLR9. J Exp Med 2010;207:2931-2942.

-93 Means TK, Latz E, Hayashi F, Murali MR, Golenbock DT, Luster AD: Human lupus autoantibody-DNA complexes activate DCs through cooperation of CD32 and TLR9. J Clin Invest 2005;115:407-417.

$94 \mathrm{Yu}$ P, Musette P, Peng SL: Toll-like receptor 9 in murine lupus: more friend than foe! Immunobiology 2008;213:151-157.

95 Ehlers M, Fukuyama H, McGaha TL, Aderem A, Ravetch JV: TLR9/MyD88 signaling is required for class switching to pathogenic IgG2a and $2 b$ autoantibodies in SLE. J Exp Med 2006;203:553-561.

96 Wu X, Peng SL: Toll-like receptor 9 signaling protects against murine lupus. Arthritis Rheum 2006;54:336-342.

$\checkmark 97$ Nickerson KM, Christensen SR, Shupe J, Kashgarian M, Kim D, Elkon K, Shlomchik MJ: TLR9 regulates TLR7- and MyD88-dependent autoantibody production and disease in a murine model of lupus. J Immunol 2010;184:1840-1848.

\$9 Zhou XJ, Lv JC, Cheng WR, Yu L, Zhao MH, Zhang H: Association of TLR9 gene polymorphisms with lupus nephritis in a Chinese Han population. Clin Exp Rheumatol 2010;28:397-400.

$\$ 99$ Papadimitraki ED, Choulaki C, Koutala E, Bertsias G, Tsatsanis C, Gergianaki I, Raptopoulou A, Kritikos HD, Mamalaki C, Sidiropoulos P, Boumpas DT: Expansion of toll-like receptor 9-expressing B cells in active systemic lupus erythematosus: implications for the induction and maintenance of the autoimmune process. Arthritis Rheum 2006;54:3601-3611.

100 Tian J, Avalos AM, Mao SY, Chen B, Senthil K, Wu H, Parroche P, Drabic S, Golenbock D, Sirois C, Hua J, An LL, Audoly L, La Rosa G, Bierhaus A, Naworth P, Marshak-Rothstein A, Crow MK, Fitzgerald KA, Latz E, Kiener PA, Coyle AJ: Toll-like receptor 9-dependent activation by DNA-containing immune complexes is mediated by HMGB1 and RAGE. Nat Immunol 2007;8: 487-496.

101 Park JS, Gamboni-Robertson F, He Q, Svetkauskaite D, Kim JY, Strassheim D, Sohn JW, Yamada S, Maruyama I, Banerjee A, Ishizaka A, Abraham E: High mobility group box 1 protein interacts with multiple Toll-like receptors. Am J Physiol Cell Physiol 2006;290:C917-C924.

102 Ulloa L, Messmer D: High-mobility group box 1 (HMGB1) protein: friend and foe. Cytokine Growth Factor Rev 2006; 17:189201.
03 Urbonaviciute V, Furnrohr BG, Meister S, Munoz L, Heyder P, De Marchis F, Bianchi ME, Kirschning $\mathrm{C}$, Wagner $\mathrm{H}$, Manfredi AA, Kalden JR, Schett G, Rovere-Querini P, Herrmann M, Voll RE: Induction of inflammatory and immune responses by HMGB1-nucleosome complexes: implications for the pathogenesis of SLE. J Exp Med 2008;205:3007-3018.

104 Patole PS, Pawar RD, Lichtnekert J, Lech M, Kulkarni OP, Ramanjaneyulu A, Segerer S, Anders HJ: Coactivation of Toll-like receptor- 3 and -7 in immune complex glomerulonephritis. J Autoimmun 2007;29:52-59.

105 Vollmer J, Tluk S, Schmitz C, Hamm S, Jurk M, Forsbach A, Akira S, Kelly KM, Reeves WH, Bauer S, Krieg AM: Immune stimulation mediated by autoantigen binding sites within small nuclear RNAs involves Tolllike receptors 7 and 8. J Exp Med 2005;202: 1575-1585.

-106 Deane JA, Pisitkun P, Barrett RS, Feigenbaum L, Town T, Ward JM, Flavell RA, Bolland S: Control of toll-like receptor 7 expression is essential to restrict autoimmunity and dendritic cell proliferation. Immunity 2007;27:801-810.

107 Komatsuda A, Wakui H, Iwamoto K, Ozawa $M$, Togashi $M$, Masai $R$, Maki $N$, Hatakeyama T, Sawada K: Up-regulated expression of Toll-like receptors mRNAs in peripheral blood mononuclear cells from patients with systemic lupus erythematosus. Clin Exp Immunol 2008;152:482-487.

108 Hawn TR, Wu H, Grossman JM, Hahn BH, Tsao BP, Aderem A: A stop codon polymorphism of Toll-like receptor 5 is associated with resistance to systemic lupus erythematosus. Proc Natl Acad Sci USA 2005; 102: 10593-10597.

109 Furnrohr BG, Wach S, Kelly JA, Haslbeck M, Weber CK, Stach CM, Hueber AJ, Graef D, Spriewald BM, Manger K, Herrmann M, Kaufman KM, Frank SG, Goodmon E, James JA, Schett G, Winkler TH, Harley JB, Voll RE: Polymorphisms in the Hsp70 gene locus are genetically associated with systemic lupus erythematosus. Ann Rheum Dis 2010;69:1983-1989.

110 Vargas-Alarcon G, Granados J, MartinezLaso J, Gomez-Casado E, Zuniga J, Salgado $\mathrm{N}$, Hernandez-Pacheco G, Hesiquio R, Rodriguez-Reyna TS, Gamboa R, AlcocerVarela J, Arnaiz-Villena A: Lack of association between the polymorphism at the heatshock protein (HSP70-2) gene and systemic lupus erythematosus (SLE) in the Mexican mestizo population. Genes Immun 2000;1: 367-370.

111 Asea A, Rehli M, Kabingu E, Boch JA, Bare O, Auron PE, Stevenson MA, Calderwood SK: Novel signal transduction pathway utilized by extracellular HSP70: role of tolllike receptor (TLR) 2 and TLR4. J Biol Chem 2002;277:15028-15034. 
-112 Mathur S, Walley KR, Wang Y, Indrambarya T, Boyd JH: Extracellular heat shock protein 70 induces cardiomyocyte inflammation and contractile dysfunction via TLR2. Circ J 2011;75:2445-2452.

-113 Tsan MF, Gao B: Heat shock proteins and immune system. J Leukoc Biol 2009;85: 905-910.

-114 Patole PS, Grone HJ, Segerer S, Ciubar R, Belemezova E, Henger A, Kretzler M, Schlondorff D, Anders HJ: Viral doublestranded RNA aggravates lupus nephritis through Toll-like receptor 3 on glomerular mesangial cells and antigen-presenting cells. J Am Soc Nephrol 2005;16:1326-1338.

115 Castiblanco J, Varela DC, Castano-Rodriguez N, Rojas-Villarraga A, Hincapie ME, Anaya JM: TIRAP (MAL) S180L polymorphism is a common protective factor against developing tuberculosis and systemic lupus erythematosus. Infect Genet Evol 2008;8:541-544.

-116 Kimkong I, Avihingsanon Y, Hirankarn N: Expression profile of HIN200 in leukocytes and renal biopsy of SLE patients by realtime RT-PCR. Lupus 2009;18:1066-1072.

-117 Murphy S, Nguyen VH: Role of gut microbiota in graft-versus-host disease. Leuk Lymphoma 2011;52:1844-1856.

-118 Elmaagacli AH, Koldehoff M, Hindahl H, Steckel NK, Trenschel R, Peceny R, Ottinger H, Rath PM, Ross RS, Roggendorf M, Grosse-Wilde H, Beelen DW: Mutations in innate immune system NOD2/CARD 15 and TLR-4 (Thr399Ile) genes influence the risk for severe acute graft-versus-host disease in patients who underwent an allogeneic transplantation. Transplantation 2006;81:247-254.

-119 Holler E, Rogler G, Herfarth H, Brenmoehl J, Wild PJ, Hahn J, Eissner G, Scholmerich J, Andreesen R: Both donor and recipient NOD2/CARD15 mutations associate with transplant-related mortality and GvHD following allogeneic stem cell transplantation. Blood 2004;104:889-894.

120 Penack O, Smith OM, Cunningham-Bussel A, Liu X, Rao U, Yim N, Na IK, Holland AM, Ghosh A, Lu SX, Jenq RR, Liu C, Murphy GF, Brandl K, van den Brink MR: NOD2 regulates hematopoietic cell function during graft-versus-host disease. J Exp Med 2009;206:2101-2110.

-121 Sato H, Williams HR, Spagnolo P, Abdallah A, Ahmad T, Orchard TR, Copley SJ, Desai SR, Wells AU, du Bois RM, Welsh KI: CARD15/NOD2 polymorphisms are associated with severe pulmonary sarcoidosis. Eur Respir J 2010;35:324-330.

122 Martin TM, Doyle TM, Smith JR, Dinulescu D, Rust K, Rosenbaum JT: Uveitis in patients with sarcoidosis is not associated with mutations in NOD2 (CARD15). Am J Ophthalmol 2003;136:933-935.
123 Tanabe T, Ishige I, Suzuki Y, Aita Y, Furukawa A, Ishige Y, Uchida K, Suzuki T, Takemura T, Ikushima S, Oritsu M, Yokoyama T, Fujimoto Y, Fukase K, Inohara N, Nunez G, Eishi Y: Sarcoidosis and NOD1 variation with impaired recognition of intracellular Propionibacterium acnes. Biochim Biophys Acta 2006;1762:794-801.

124 de Koning HD, Bodar EJ, van der Meer JW, Simon A: Schnitzler syndrome: beyond the case reports: review and follow-up of $94 \mathrm{pa}-$ tients with an emphasis on prognosis and treatment. Semin Arthritis Rheum 2007;37: 137-148.

125 Ryan JG, de Koning HD, Beck LA, Booty MG, Kastner DL, Simon A: IL-1 blockade in Schnitzler syndrome: ex vivo findings correlate with clinical remission. J Allergy Clin Immunol 2008;121:260-262.

126 de Koning HD, Schalkwijk J, van der Meer JW, Simon A: Successful canakinumab treatment identifies IL-1beta as a pivotal mediator in Schnitzler syndrome. J Allergy Clin Immunol 2011;128:1352-1354.

127 Loock J, Lamprecht P, Timmann C, Mrowietz U, Csernok E, Gross WL: Genetic predisposition (NLRP3 V198M mutation) for IL-1-mediated inflammation in a patient with Schnitzler syndrome. J Allergy Clin Immunol 2010;125:500-502.

128 de Koning HD, Bodar EJ, Simon A, van der Hilst JC, Netea MG, van der Meer JW: Beneficial response to anakinra and thalidomide in Schnitzler's syndrome. Ann Rheum Dis 2006;65:542-544.

129 Gran JT, Midtvedt O, Haug S, Aukrust P: Treatment of Schnitzler's syndrome with anakinra: report of three cases and review of the literature. Scand J Rheumatol 2011; 40:74-79.

130 Buchau AS, Schauber J, Hultsch T, Stuetz A, Gallo RL: Pimecrolimus enhances TLR2/6induced expression of antimicrobial peptides in keratinocytes. J Invest Dermatol 2008;128:2646-2654.

131 Vollmer J, Krieg AM: Immunotherapeutic applications of $\mathrm{CpG}$ oligodeoxynucleotide TLR9 agonists. Adv Drug Deliv Rev 2009; 61:195-204.

132 Kuznik A, Bencina M, Svajger U, Jeras M, Rozman B, Jerala R: Mechanism of endosomal TLR inhibition by antimalarial drugs and imidazoquinolines. J Immunol 2011;186:4794-4804.

133 Sato T, Yamamoto M, Shimosato T, Klinman DM: Accelerated wound healing mediated by activation of Toll-like receptor 9 . Wound Repair Regen 2010;18:586-593.

134 Yamamoto M, Sato T, Beren J, Verthelyi D, Klinman DM: The acceleration of wound healing in primates by the local administration of immunostimulatory CpG oligonucleotides. Biomaterials 2011;32:4238-4242.
35 Barrat FJ, Meeker T, Chan JH, Guiducci C, Coffman RL: Treatment of lupus-prone mice with a dual inhibitor of TLR7 and TLR9 leads to reduction of autoantibody production and amelioration of disease symptoms. Eur J Immunol 2007;37:35823586.

136 Guiducci C, Gong M, Xu Z, Gill M, Chaussabel D, Meeker T, Chan JH, Wright T, Punaro M, Bolland S, Soumelis V, Banchereau J, Coffman RL, Pascual V, Barrat FJ: TLR recognition of self-nucleic acids hampers glucocorticoid activity in lupus. Nature 2010;465:937-941.

137 Hemmi H, Kaisho T, Takeuchi O, Sato S, Sanjo H, Hoshino K, Horiuchi T, Tomizawa H, Takeda K, Akira S: Small anti-viral compounds activate immune cells via the TLR7 MyD88-dependent signaling pathway. Nat Immunol 2002;3:196-200.

138 Schon MP, Schon M: TLR7 and TLR8 as targets in cancer therapy. Oncogene 2008;27: 190-199.

139 Lacarrubba F, Potenza MC, Gurgone S, Micali G: Successful treatment and management of large superficial basal cell carcinomas with topical imiquimod 5\% cream: a case series and review. J Dermatolog Treat 2011;22:353-358.

140 Micali G, Lacarrubba F, Dinotta F, Massimino D, Nasca MR: Treating skin cancer with topical cream. Expert Opin Pharmacother 2010;11:1515-1527.

141 Ganjian S, Ourian AJ, Shamtoub G, Wu JJ, Murase JE: Off-label indications for imiquimod. Dermatol Online J 2009;15:4.

142 Valins W, Amini S, Berman B: The expression of toll-like receptors in dermatological diseases and the therapeutic effect of current and newer topical toll-like receptor modulators. J Clin Aesthet Dermatol 2010;3:20-29.

143 Testerman TL, Gerster JF, Imbertson LM, Reiter MJ, Miller RL, Gibson SJ, Wagner TL, Tomai MA: Cytokine induction by the immunomodulators imiquimod and S-27609. J Leukoc Biol 1995;58:365-372.

144 Suzuki H, Wang B, Shivji GM, Toto P, Amerio P, Tomai MA, Miller RL, Sauder DN: Imiquimod, a topical immune response modifier, induces migration of Langerhans cells. J Invest Dermatol 2000;114:135-141.

145 Urosevic M, Dummer R, Conrad C, Beyeler M, Laine E, Burg G, Gilliet M: Disease-independent skin recruitment and activation of plasmacytoid predendritic cells following imiquimod treatment. J Natl Cancer Inst 2005;97:1143-1153.

146 Szeimies RM, Bichel J, Ortonne JP, Stockfleth E, Lee J, Meng TC: A phase II doseranging study of topical resiquimod to treat actinic keratosis. Br J Dermatol 2008;159: 205-210.

147 Fife KH, Meng TC, Ferris DG, Liu P: Effect of resiquimod $0.01 \%$ gel on lesion healing and viral shedding when applied to genital herpes lesions. Antimicrob Agents Chemother 2008;52:477-482. 
148 Mark KE, Corey L, Meng TC, Magaret AS, Huang ML, Selke S, Slade HB, Tyring SK, Warren T, Sacks SL, Leone P, Bergland VA, Wald A: Topical resiquimod $0.01 \%$ gel decreases herpes simplex virus type 2 genital shedding: a randomized, controlled trial. J Infect Dis 2007;195:1324-1331.

149 Craft N, Bruhn KW, Nguyen BD, Prins R, Lin JW, Liau LM, Miller JF: The TLR7 agonist imiquimod enhances the anti-melanoma effects of a recombinant Listeria monocytogenes vaccine. J Immunol 2005; 175 : 1983-1990.

150 Adams S, O’Neill DW, Nonaka D, Hardin E, Chiriboga L, Siu K, Cruz CM, Angiulli A, Angiulli F, Ritter E, Holman RM, Shapiro RL, Berman RS, Berner N, Shao Y, Manches O, Pan L, Venhaus RR, Hoffman EW, Jungbluth A, Gnjatic S, Old L, Pavlick AC, Bhardwaj N: Immunization of malignant melanoma patients with full-length NYESO-1 protein using TLR7 agonist imiquimod as vaccine adjuvant. J Immunol 2008; 181:776-784.
151 Heil F, Ahmad-Nejad P, Hemmi H, Hochrein $\mathrm{H}$, Ampenberger F, Gellert T, Dietrich H, Lipford G, Takeda K, Akira S, Wagner H, Bauer S: The Toll-like receptor 7 (TLR7)specific stimulus loxoribine uncovers a strong relationship within the TLR7, 8 and 9 subfamily. Eur J Immunol 2003;33:29872997.

152 Dzopalic T, Dragicevic A, Vasilijic S, Vucevic D, Majstorovic I, Bozic B, Balint B, Colic M: Loxoribine, a selective Toll-like receptor 7 agonist, induces maturation of human monocyte-derived dendritic cells and stimulates their Th-1- and Th-17-polarizing capability. Int Immunopharmacol 2010;10:1428-1433.
153 Agarwala SS, Kirkwood JM, Bryant J: Phase 1 , randomized, double-blind trial of 7-allyl8-oxoguanosine (loxoribine) in advanced cancer. Cytokines Cell Mol Ther 2000;6: 171-176.

154 Krieg AM: Development of TLR9 agonists for cancer therapy. J Clin Invest 2007;117: 1184-1194.

155 Krieg AM: Toll-like receptor 9 (TLR9) agonists in the treatment of cancer. Oncogene 2008;27:161-167.

156 Najar HM, Dutz JP: Topical CpG enhances the response of murine malignant melanoma to dacarbazine. J Invest Dermatol 2008; 128:2204-2210.

157 So EY, Ouchi T: The application of Toll-like receptors for cancer therapy. Int J Biol Sci 2010;6:675-681. 